\title{
Gluten-free cookies elaborated with buckwheat flour, millet flour and chia seeds
}

\author{
Lara Tatiane Geremias Ferreira BRITES ${ }^{1}$, Fernanda ORTOLAN ${ }^{2}$, David Wesley da SILVA ${ }^{1}$, Fábio Rodrigo BUENO ${ }^{1}$, \\ Thais de Souza ROCHA ${ }^{3}$, Yoon Kil CHANG ${ }^{1}$, Caroline Joy STEEL ${ }^{1 *}$
}

\begin{abstract}
The aim of this study was to obtain an optimized gluten-free cookie formulation using alternative flours. For this, a $2^{2}$ central composite rotatable design (CCRD), with varying concentrations of millet flour (MF) and chia seeds (CS), on a base of buckwheat flour (BF), was used. Control cookies were elaborated with 100\% wheat flour (WF). The cookies were characterized for texture and other physical tests and by scanning electron microscopy of their internal structure. The response surfaces for the quality parameters of the cookies showed that the higher the proportion of MF used in the formulations, the lower the height and the greater the diameter, expansion factor, and hardness of the cookies. The addition of up to $10 \%$ CS showed no influence on the responses. The optimum point was defined as that with diameter, expansion factor, thickness, and hardness closer to the control cookie: $7.5 \%$ CS, $40 \% \mathrm{MF}$, and $52.5 \% \mathrm{BF}$. The substitution of wheat flour by buckwheat flour, millet flour, and chia seeds can be considered a suitable alternative for the preparation of gluten-free cookies.
\end{abstract}

Keywords: gluten-free cookies; buckwheat flour; millet flour; chia seeds.

Practical Application: A new alternative for the manufacture of gluten-free cookies as an option for celiac patients.

\section{Introduction}

Celiac disease is an immune-mediated enteropathy triggered by exposure to dietary gluten and related to the consumption of wheat, rye, barley, and derivatives (Murray, 1999). Intolerance to gluten leads to inflammation of the mucosa of the small intestine, promoting deficiency in nutrient uptake (Feighery, 1999; Rostom et al., 2005), and a gluten-free diet is the only form of treatment.

The production of gluten-free products is a major challenge for the food industry, especially in the manufacture of bakery products, since gluten plays a key technological role in the structure of these products (Torbica et al., 2012). The limited number of gluten-free products on the market has evidenced the difficulty of developing these products. Gluten-free cookies can be considered as alternative products in the development of gluten-free foods, since they have a wide range of shapes and flavors, and great acceptance by consumers.

Flours derived from fruits, leaves, grains, tubers, and vegetables (Granato \& Ellendersen, 2009) can be used as alternatives to replace wheat flour, including buckwheat flour and millet flour. Buckwheat (Fagopyrum esculentum) is a pseudocereal that presents proteins of high biological value, as well as fibers, minerals, and flavonoids (Pomeranz, 1988; Ikeda \& Yamashita, 1994; Abdel-Aal \& Wood, 2005; Choi \& Ma, 2006). Millet (Panicum milliaceum) is considered a grain of secondary culture, mainly used for animal feed, with a worldwide production of more than 27 million tons (Ačko, 2012; Chandrasekara et al., 2012; Food and Agriculture
Organization of the United Nations, 2011). This grain is a good source of energy due to its high starch content (Arendt \& Dal Bello, 2009; Demirbas, 2005).

Gluten-free cookies can also be enriched with constituents that play a nutritional or physiological role in the human body (Feddern et al., 2011; Moroni et al., 2011; Torbica et al., 2012), such as chia (Salvia hispanica L.) seeds or flour, which are rich in fiber, proteins, essential fatty acids such as omega- 3 and 6 fatty acids, vitamins and antioxidants, and have been studied to enrich foods, especially with dietary fiber (Capitani et al., 2012; Muñoz et al., 2012; Coelho \& Salas-Mellado, 2015).

This study aimed to elaborate gluten-free cookies with buckwheat flour, millet flour, and chia seeds, using an experimental design to prepare cookies with texture and physical characteristics similar to those produced with wheat flour.

\section{Material and methods}

\subsection{Material}

Wheat (Triticum aestivum L.) flour, chia (Salvia hispanica L.) seeds, hulled millet (Panicum miliaceum) grains and the other ingredients used in the formulations were purchased commercially in Campinas - SP. Buckwheat (Fagopyrum spp) grains were donated by Mãe Terra (Osasco - SP), and palm oil was donated by Triângulo Alimentos (Itápolis - SP). 


\subsection{Methods}

\section{Production of millet and buckwheat flours}

To obtain flours, whole millet and buckwheat grains were milled in a Quadrumat Senior (Brabender ${ }^{\mathrm{rm}}$, Duisburg, Germany) mill, without the use of the set of sieves, to give whole grain flour, according to method 26-50.01 (American Association of Cereal Chemists, 2010), with adaptations.

\section{Physicochemical characterization of raw materials}

The physicochemical characterization of wheat flour (WF), buckwheat flour (BF), millet flour (MF), and chia seeds (CS) was performed according to the methods proposed by the American Association of Cereal Chemists (2010), as follows: moisture (method 44-15.02); ash (method 08-01.01); proteins (46-13.01 method); ether extract (method 30-10.01); and total dietary fiber (method 32-05.01). The digestible carbohydrates were determined by difference [100 - (ash + protein + ether extract + total dietary fiber)]. The particle size was measured by method 66-20.01 (American Association of Cereal Chemists, 2010) and color measurements were performed by the CIELab system, using a portable colorimeter MiniScan XE Plus (Hunterlab, Reston, VA, USA).

The viscoamylographic behavior (pasting temperature, peak viscosity, trough viscosity, breakdown, final viscosity, and tendency to retrogradation or setback) was determined according to methodology 162 of the International Association for Cereal Science and Technology (1996), in a Rapid Visco Analyser (RVA), model 4500 (Perten, Warriewood, Australia).

The content of apparent amylose was determined by spectrophotometry, as described in method 61-03.01 (American Association of Cereal Chemists, 2010). The absorbance of the samples was determined with a spectrophotometer DU-70n (Beckman, Fullerton, USA), at a wavelength of $620 \mathrm{~nm}$.

\section{Experimental design}

A $2^{2}$ central composite rotatable design (CCRD) was used, with four factorial points, four axial points, and three central points, to investigate the effect of the addition of different levels of CS, MF, and BF on the physical characteristics of gluten-free cookies. For the design, the percentage of CS and MF were considered as independent variables and $\mathrm{BF}$ was used to complete the flour mix. The levels of the variables are presented in Table 1. Maximum and minimum levels were determined in pre-tests.

\section{Manufacture of gluten-free cookies}

The formulation shown in Table 2 was used for the manufacture of the cookies, based on method 10-50.05 (American Association of Cereal Chemists, 2010). Control cookies with 100\% WF and gluten-free cookies with $100 \% \mathrm{BF}$ and $100 \% \mathrm{MF}$ were prepared, in addition to cookies made following the experimental design.

The cookie dough was processed in a planetary mixer (model K45SS, KitchenAid ${ }^{\mathrm{TM}}$, St. Joseph, USA). Hydrogenated fat, sugar, salt, and sodium bicarbonate were blended for 3 minutes at $58 \mathrm{rpm}$. Thereafter, dextrose and distilled water were added, the dough was mixed for one minute at $58 \mathrm{rpm}$ and one minute at
$220 \mathrm{rpm}$. Then, the flour or the flour blend and CS were added and mixed for two minutes at $220 \mathrm{rpm}$.

Dough was divided into portions ( $200 \mathrm{~g})$, laminated (13 mm thickness), and cut with a stainless steel mold (60 mm diameter). The cookies were baked at $150{ }^{\circ} \mathrm{C}$ for 15 minutes in an electric oven (model C6, Prática Technicook, Pouso Alegre, MG, Brazil). One hour after baking, the cookies were weighed and placed in plastic polypropylene bags, and stored in a dry place protected from light.

\section{Physical characterization of the cookies}

Weight loss was determined by the change in weight of the dough pieces after baking. The diameter and thickness of the cookies were measured with a caliper, and the expansion factor was obtained by dividing the diameter by the thickness values, according to method 10-50.05 (American Association of Cereal Chemists, 2010). The volume and density of the cookies were calculated according to Mauro et al. (2010).

Texture was evaluated in a texture analyzer (model TA-XT2i, Stable Micro Systems, Surrey, United Kingdom) using a three point bending rig (HDP/3PB) to determine hardness (Silva et al., 1999). The test conditions were: pre-test speed $1 \mathrm{~mm} / \mathrm{s}$, test speed $3 \mathrm{~mm} / \mathrm{s}$, post-test speed $10 \mathrm{~mm} / \mathrm{s}$, and penetration distance $25 \mathrm{~mm}$.

The micrographs of the control cookies and optimum point were obtained by scanning electron microscopy, using a Leo 440i LEO Electron Microscope (Cambridge, England), $20 \mathrm{kV}$ accelerating voltage and $100 \mathrm{pA}$ beam current. The cookies were broken into small pieces $(\sim 40 \mathrm{~mm})$, and put on a metal disc using a carbon adhesive tape, which was sputtered (Balzers

Table 1. Levels of the variables of the $2^{2}$ experimental design.

\begin{tabular}{ccccccc}
\hline Coded & Real & \multicolumn{5}{c}{ Levels } \\
\hline Variables & Variables $^{*}$ & $-\alpha$ & -1 & 0 & +1 & $+\alpha$ \\
$\mathbf{x}_{1}$ & CS (\%) & 0 & 1.4 & 5 & 8.6 & 10 \\
$\mathbf{x}_{2}$ & MF (\%) & 10 & 21.6 & 50 & 78.4 & 90 \\
\hline
\end{tabular}

${ }^{\star}$ Real values (\% substitution of buckwheat flour); $\mathrm{x}_{1}$ - chia seeds (CS) and $\mathrm{x}_{2}$ - millet flour $(\mathrm{MF}) ; \%$ buckwheat flour $(\mathrm{BF})=[100-(\mathrm{CS}+\mathrm{MF})]$.

Table 2. Base formulation for the manufacture of cookies.

\begin{tabular}{ccc}
\hline Ingredients & Amount $^{*}$ & Amount $^{* *}$ \\
\hline Wheat flour (WF) & $225 \mathrm{~g}$ & - \\
Buckwheat flour (BF) & - & $* *$ \\
Millet flour (MF) & - & $* *$ \\
Chia seeds (CS) & - & $* *$ \\
Refined sugar & $130 \mathrm{~g}$ & $130 \mathrm{~g}$ \\
Palm oil & $64 \mathrm{~g}$ & $64 \mathrm{~g}$ \\
Sodium bicarbonate & $2.5 \mathrm{~g}$ & $2.5 \mathrm{~g}$ \\
Salt & $2.1 \mathrm{~g}$ & $2.1 \mathrm{~g}$ \\
Dextrose solution & $32.8 \mathrm{~mL}$ & $32.8 \mathrm{~mL}$ \\
Distilled water & $15.5 \mathrm{~mL}$ & $15.5 \mathrm{~mL}$ \\
\hline
\end{tabular}

${ }^{*}$ According to method 10-50.05 (American Association of Cereal Chemists, 2010);

${ }^{* *}$ According to the experimental design. 
SCD 050) for application of a $20 \mathrm{~nm}$ gold layer. Measurements were carried out at 200 to $1000 \mathrm{X}$ magnification.

\section{Statistical analysis}

All analyses were carried out in triplicate, except for cookie hardness which was in 7 replicates. Tukey's test was used for comparison of the means of the characterization of the raw materials $(p \leq 0.05)$. Data for the responses (physical characteristics of the cookies) were analyzed by the Response Surface Methodology using the software Statistica 7.0 (StatSoft, 2004) for the calculation of the regression coefficients and ANOVA (minimum $\mathrm{R}^{2}$ of 0.70 and $\mathrm{p}$-value $\leq 0.10$ ). The mathematical models are presented for use with the coded values of the independent variables ( $\mathrm{x}_{1}$ and $\mathrm{x}_{2}$ for CS and MF, respectively). By evaluating the response surfaces, the optimum point was chosen as the one with the most similar characteristics to the control (100\% WF).

\section{Results and discussion}

\subsection{Physicochemical characterization of flours and chia seeds}

The results of the characterization of WF, BF, and MF flours, and CS are shown in Table 3. It is worth emphasizing that the WF and MF have similar results, as far as the proximate composition is concerned, while the BF presented higher fiber content when compared to the other flours. The CS had high levels of proteins, lipids, ash, and mainly fibers, contributing to the nutritional quality of the cookies (Charalampopoulos et al., 2002; Anderson et al., 2009).

The amylose content is a characteristic of each type of starch and influences their pasting behavior. No significant differences ( $p \leq 0.05$ ) were observed between WF and MF for the content of apparent amylose, while BF showed lower levels of this polymer. Our results are close to those found by Zheng et al. (1998) and Hung et al. (2009) for buckwheat starch, which were 21.9 to $24.6 \%$ and 21.1 to $27.4 \%$, respectively, if we consider approximately $78 \%$ starch (d.b.) in buckwheat flour (BF).

According to Demiate \& Kotovicz (2011), in general, higher amylose contents lead to higher setback values (reflecting a greater tendency to retrograde). But Schirmer et al. (2013) observed a lower the tendency to retrograde in higher amylose content starches, and related it to the formation of lipid-amylose complexes.

With respect to the color parameters, WF was lighter when compared to BF and MF, since these flours were obtained from whole grains, thus resulting in darker flours, due to the presence of bran constituents, such as fibers, phenolics, and flavonoids (Torbica et al., 2012), which contributed to the reduction of the $\mathrm{L}^{*}$ (lightness) values. Chia seeds had low lightness values, and high tendencies to red and yellow, the latter due to the presence of beta-carotene and phenolic compounds (Reyes-Caudillo et al., 2008).

Regarding the particle size, all flours presented more than $87 \%$ of particles $\leq 0.250 \mathrm{~mm}$. According to Brazilian legislation (Brasil, 2005), wheat flour must have at least $95 \%$ of its particles $\leq 0.250 \mathrm{~mm}$. The CS had $96.60 \%$ particles retained on the $0.250 \mathrm{~mm}$ sieve, which was expected, since whole seeds were used.

Among the raw materials used to produce the gluten-free cookies, it can be observed that the smallest particle size was found for MF, demonstrating that it probably has a softer endosperm when compared to buckwheat. The particle size is important in the preparation of cookies and other bakery products, considering that smaller, uniform particles generate a greater uniformity of the elaborated products, generating better texture and visual

Table 3. Proximate composition and color parameters, particle size, amylose content, and viscoamylographic profile of wheat flour (WF), buckwheat flour (BF), millet flour (MF), and chia seeds (CS).

\begin{tabular}{|c|c|c|c|c|}
\hline & WF & $\mathrm{BF}$ & MF & CS \\
\hline Moisture (g/100 g) & $11.49 \pm 0.11 b$ & $12.72 \pm 0.06 \mathrm{a}$ & $11.18 \pm 0.10 c$ & $6.61 \pm 0.01 d$ \\
\hline Protein $(\mathrm{g} / 100 \mathrm{~g})$ & $10.81 \pm 0.33 b c$ & $11.52 \pm 0.10 \mathrm{~b}$ & $10.27 \pm 0.98 \mathrm{c}$ & $20.99 \pm 0.37 \mathrm{a}$ \\
\hline Ether extract $(\mathrm{g} / 100 \mathrm{~g})$ & $1.15 \pm 0.04 c$ & $3.15 \pm 0.42 b$ & $1.92 \pm 0.47 \mathrm{c}$ & $34.49 \pm 0.90 \mathrm{a}$ \\
\hline Ash (g/100 g) & $0.51 \pm 0.01 \mathrm{c}$ & $2.15 \pm 0.03 b$ & $0.80 \pm 0.29 c$ & $4.87 \pm 0.02 \mathrm{a}$ \\
\hline Total dietary fiber (g/100 g) & $3.08 \pm 0.60 \mathrm{~b}$ & $5.10 \pm 0.31 b$ & $1.08 \pm 0.21 \mathrm{c}$ & $35.54 \pm 2.80 \mathrm{a}$ \\
\hline Digestible carbohydrates*** & $84.45 \pm 1.61 \mathrm{a}$ & $78.08 \pm 0.73 b$ & $85.93 \pm 0.31 \mathrm{a}$ & $4.11 \pm 1.27 \mathrm{c}$ \\
\hline Amylose (g/100 g) & $19.40 \pm 0.31 \mathrm{a}$ & $17.68 \pm 0.70 \mathrm{~b}$ & $19.38 \pm 0.04 a$ & n.d. ${ }^{* *}$ \\
\hline$L^{*}$ & $94.05 \pm 0.63 a$ & $86.36 \pm 0.67 b$ & $87.19 \pm 0.49 b$ & $42.32 \pm 0.91 c$ \\
\hline$a^{*}$ & $0.58 \pm 0.05 \mathrm{~d}$ & $1.49 \pm 0.08 \mathrm{c}$ & $1.95 \pm 0.07 b$ & $4.39 \pm 0.05 \mathrm{a}$ \\
\hline$b^{*}$ & $10.54 \pm 0.20 \mathrm{c}$ & $10.57 \pm 0.55 c$ & $25.33 \pm 0.20 \mathrm{a}$ & $15.43 \pm 0.37 b$ \\
\hline Particle size $(\leq 0.250 \mathrm{~mm})(\%)$ & 97.50 & 87.15 & 93.25 & 00.03 \\
\hline Pasting temperature $\left({ }^{\circ} \mathrm{C}\right)$ & $84.72 \pm 1.20 \mathrm{a}$ & $81.95 \pm 0.63 b$ & $77.65 \pm 0.37 c$ & n.d.** \\
\hline Peak viscosity (RVU) & $106.08 \pm 0.23 c$ & $182.62 \pm 5.37 \mathrm{a}$ & $151.25 \pm 3.12 b$ & n.d. ${ }^{* *}$ \\
\hline Trough viscosity (RVU) & $38.21 \pm 0.65 c$ & $159.12 \pm 0.78 \mathrm{a}$ & $78.79 \pm 0.76 b$ & n.d. ${ }^{* *}$ \\
\hline Final viscosity (RVU) & $103.08 \pm 2.63 c$ & $426.12 \pm 12.54 \mathrm{a}$ & $226.08 \pm 2.28 b$ & n.d. ${ }^{* *}$ \\
\hline Breakdown (RVU) & $67.87 \pm 0.71 b$ & $23.5 \pm 0.62 c$ & $72.46 \pm 3.82 \mathrm{a}$ & n.d. ${ }^{* *}$ \\
\hline Setback (RVU) & $63.70 \pm 1.67 c$ & $267 \pm 11.70 \mathrm{a}$ & $147.29 \pm 3.10 \mathrm{~b}$ & n.d. ${ }^{* *}$ \\
\hline
\end{tabular}

Means followed by the same letter on the lines do not differ significantly by Tukey's test $(\mathrm{p} \leq 0.05) ;{ }^{* *}$.d. $=$ not determined; ${ }^{* * *}$ Digestible carbohydrates $=[100-($ ash + protein + ether extract + total dietary fiber)]. 
aspect, due to a more homogeneous absorption of water, and more uniform cooking (Silva et al., 2009). According to Yamamoto et al. (1996), the particle size is an important parameter for final cookie quality, due to a greater uniformity during the preparation of the dough, resulting in more uniform baking.

As observed in the viscoamylographic profile of the flours WF, BF, and MF, significant differences were found for all of them, mainly due to the different ratios of starch and fibers. The WF had the lowest values of peak viscosity, final viscosity, and setback, when compared to the other flours, probably due to differences in protein profile, since only the WF has gluten-forming proteins, which interact with the surface of the starch granule, preventing further interaction with water (Chen et al., 2010; Ragaee \& Abdel-Aal, 2006). The results obtained for wheat flour are within the range presented by Zhang et al. (2005), who found a wide variation for flours from different wheat grain cultivars. The results for buckwheat flour are in accordance with Inglett et al. (2009). However, we did not find results for pasting properties of millet flour in the literature consulted.

In products without gluten there is a deficiency to identify the quality of the flours used in formulations, and determining the viscoamylographic properties may help in the characterization of the starch paste, helping to predict the baking time and the behavior of the cooked starch in the cookies (Inglett et al., 2009). Besides this, these results may be interesting for other studies involving other applications, since little information of this kind is found for raw materials such as MF in the literature.

According to Schirmer et al. (2013), when the amount of amylopectin is higher in relation to amylose in the starch granules, there is a higher viscosity during heating. This effect was also observed in this study, where the BF had the lowest amylose content when compared to WF and MF (Table 3). However, a higher setback value, which is usually associated with higher amylose content, was also observed for the BF, probably due to its high fiber content when compared to the other raw materials. According to Nuwamanya et al. (2010) and Ascheri et al. (2012), the fiber content influences the starch paste viscosity, increasing maximum viscosity and setback.

One of the main problems encountered in gluten-free products is aging and hardening during storage. This problem is related to the re-association of the starch molecules (amylose and amylopectin) after cooling of the gelatinized starch paste, this phase being pointed out in the RVA as the setback, indicating the tendency of starch to retrograde (Singh et al., 2011). However, this may be a problem for breads and cakes, products which must remain soft during their shelf-life, but not so for cookies. In this case, retrogradation may even be seen as positive.

The higher the tendency to retrograde, the greater the chance of the product to harden during storage, indicating that cookies made with higher proportions of BF can become more rigid during storage, making it necessary to carry out shelf-life studies in future research. However, in agreement with Ragaee \& Abdel-Aal (2006), the amylose content is responsible for the initial retrogradation of the starch (soon after cooling), which may justify the higher hardness values found in cookies produced with higher levels of MF, that presented higher amylose content.

Another interesting property of starch pastes is breakdown viscosity, which indicates the stability of the starch granules during heating and mechanical agitation (Demiate \& Kotovicz, 2011). The lowest values for breakdown were observed for BF, which may be interesting for use in sauces and confectionery creams, but not so relevant for products such as cookies.

BF showed the highest final viscosity and hence the greater tendency to retrogradation or setback, followed by MF and WF. The values obtained for the viscoamylographic profile may indicate different behaviors in processing and baking.

\subsection{Physical characteristics of gluten-free cookies}

The physical characteristics of gluten-free cookies are shown in Table 4.

Table 4. Physical characteristics of cookies prepared with different levels of CS, MF, and BF according to the $2^{2}$ CCRD, and control formulations with $100 \% \mathrm{WF}, 100 \% \mathrm{BF}$, and $100 \% \mathrm{MF}$.

\begin{tabular}{|c|c|c|c|c|c|c|c|c|}
\hline Trials & $\begin{array}{c}\% \mathrm{CS} \\
\mathrm{x}_{1}(\mathrm{CS}) \\
\end{array}$ & $\begin{array}{c}\% \mathrm{MF} \\
\mathrm{x}_{2}(\mathrm{MF})\end{array}$ & $\begin{array}{c}\% \mathrm{BF} \\
100-(\mathrm{CS}+\mathrm{MF}) \\
\end{array}$ & $\begin{array}{l}\text { Weight } \\
(\mathrm{g})\end{array}$ & $\begin{array}{c}\text { Diameter } \\
(\mathrm{mm})\end{array}$ & $\begin{array}{c}\text { Thickness } \\
(\mathrm{mm})\end{array}$ & $\begin{array}{c}\text { Expansion } \\
\text { Factor }\end{array}$ & $\begin{array}{c}\text { Hardness } \\
(\mathrm{N})\end{array}$ \\
\hline $\mathrm{F} 1$ & $-1(1.4)$ & $-1(21.6)$ & 77.0 & $30.46 \pm 1.58$ & $69.28 \pm 2.32$ & $15.63 \pm 0.70$ & $4.43 \pm 0.10$ & $84.27 \pm 7.80$ \\
\hline F2 & $+1(8.6)$ & $-1(21.6)$ & 69.8 & $29.99 \pm 1.91$ & $70.57 \pm 2.41$ & $14.79 \pm 0.83$ & $6.74 \pm 0.43$ & $73.33 \pm 24.80$ \\
\hline F3 & $-1(1.4)$ & $+1(78.4)$ & 20.2 & $28.15 \pm 2.02$ & $83.41 \pm 1.47$ & $12.41 \pm 0.91$ & $4.79 \pm 0.33$ & $147.62 \pm 5.21$ \\
\hline $\mathrm{F} 4$ & $+1(8.6)$ & $+1(78.4)$ & 13.0 & $28.55 \pm 1.27$ & $86.1 \pm 1.90$ & $10.4 \pm 0.66$ & $8.29 \pm 0.38$ & $146.37 \pm 18.52$ \\
\hline F5 & $-1.41(0.0)$ & $0(50.0)$ & 50.0 & $29.33 \pm 0.10$ & $74.11 \pm 0.92$ & $14.38 \pm 0.61$ & $5.16 \pm 0.27$ & $59.88 \pm 1.33$ \\
\hline F6 & $+1.41(10.0)$ & $0(50.0)$ & 40.0 & $27.72 \pm 0.82$ & $77.65 \pm 2.68$ & $12.09 \pm 0.80$ & $6.46 \pm 0.61$ & $68.39 \pm 12.10$ \\
\hline F7 & $0(5.0)$ & $-1.41(10.0)$ & 85.0 & $28.52 \pm 1.17$ & $68.65 \pm 1.00$ & $14.92 \pm 0.74$ & $4.61 \pm 0.28$ & $81.67 \pm 7.45$ \\
\hline F8 & $0(5.0)$ & $+1.41(90.0)$ & 5.0 & $27.44 \pm 2.33$ & $85.27 \pm 2.75$ & $10.52 \pm 0.80$ & $8.15 \pm 0.71$ & $153.95 \pm 23.80$ \\
\hline F9 & $0(5.0)$ & $0(50.0)$ & 45.0 & $29.11 \pm 1.86$ & $75.73 \pm 1.33$ & $14.22 \pm 0.53$ & $5.33 \pm 0.29$ & $36.05 \pm 4.12$ \\
\hline F10 & $0(5.0)$ & $0(50.0)$ & 45.0 & $28.41 \pm 1.74$ & $75.06 \pm 1.45$ & $13.87 \pm 0.40$ & $5.41 \pm 0.19$ & $48.46 \pm 1.90$ \\
\hline F11 & $0(5.0)$ & $0(50.0)$ & 45.0 & $28.59 \pm 1.44$ & $76.28 \pm 0.91$ & $13.9 \pm 0.72$ & $5.50 \pm 0.29$ & $70.07 \pm 6.10$ \\
\hline \multicolumn{4}{|c|}{ Control $100.0 \%$ WF } & $29.10 \pm 1.21$ & $69.80 \pm 0.66$ & $15.90 \pm 0.95$ & $4.40 \pm 0.20$ & $174.38 \pm 14.27$ \\
\hline \multicolumn{4}{|c|}{ Control 100.0\% BF } & $28.60 \pm 1.30$ & $68.10 \pm 1.10$ & $15.60 \pm 1.00$ & $4.48 \pm 0.30$ & $83.66 \pm 14.20$ \\
\hline \multicolumn{4}{|c|}{ Control $100.0 \%$ MF } & $26.60 \pm 1.70$ & $83.60 \pm 1.60$ & $10.10 \pm 1.10$ & $8.39 \pm 0.90$ & $132.84 \pm 7.80$ \\
\hline
\end{tabular}

$\mathrm{CS}=$ chia seeds; $\mathrm{MF}=$ millet flour; $\mathrm{BF}=$ buckwheat flour; $\mathrm{WF}=$ wheat flour. 

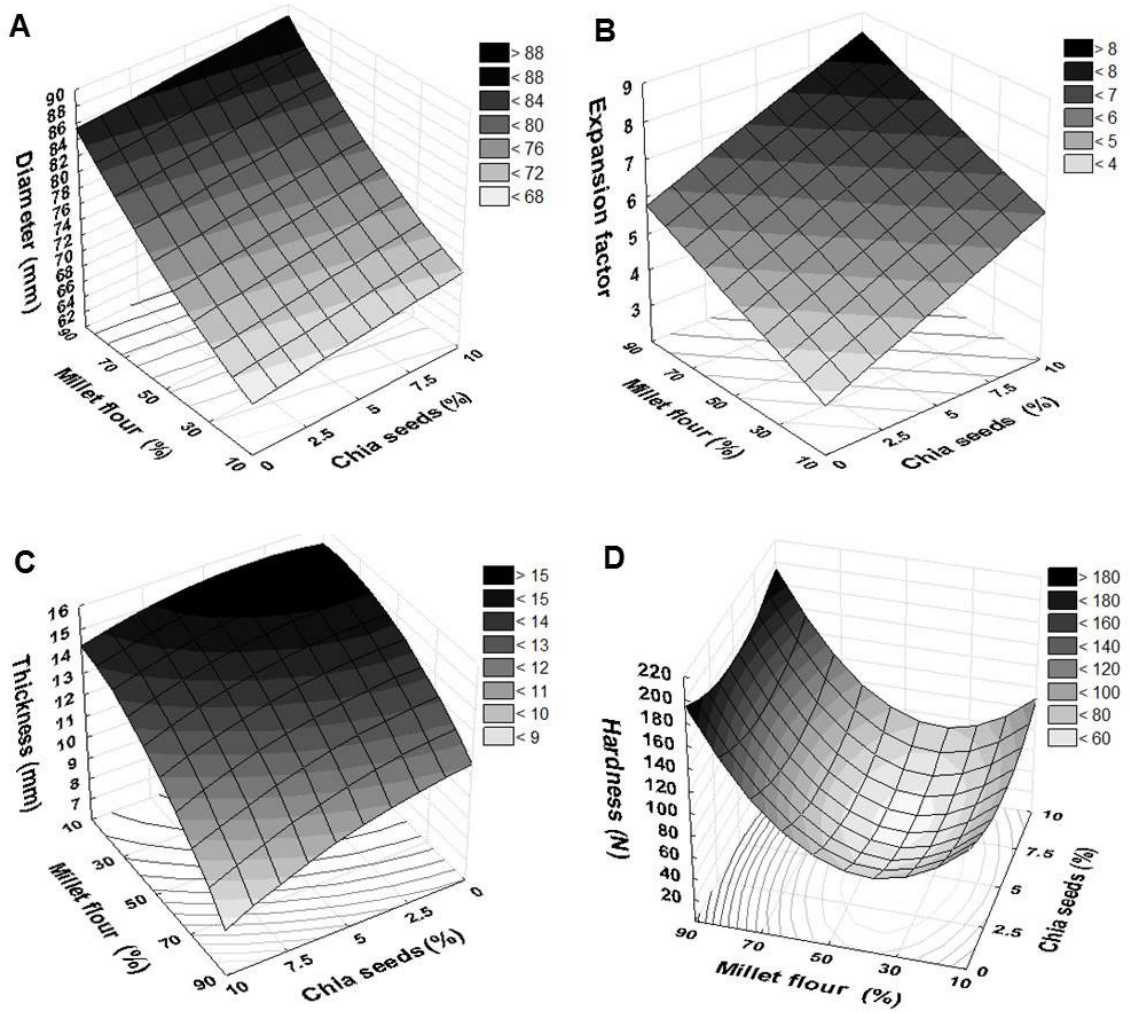

Figure 1. Response surfaces of the cookies prepared with different levels of chia seeds, millet flour, and buckwheat flour, for: (A) diameter (mm); (B) expansion factor; (C) thickness (mm); (D) hardness (N).

Figure 1 shows the response surfaces for the parameters diameter, thickness, expansion factor, and hardness of the cookies prepared with different levels of CS, MF, and BF.

As shown in Figure 1A (Diameter $=75.99+1.12 x_{1}+6.66 x_{2}+0.78 x_{2}^{2}$; $\left.\mathrm{R}^{2}=97.80 \% ; \mathrm{Fcal} / \mathrm{Ftab}=33.91\right)$ and $1 \mathrm{~b}($ Expansion factor $\left.=5.89+0.96 x_{1}+0.87 x_{2} ; \mathrm{R}^{2}=73.36 \% ; \mathrm{Fcal} / \mathrm{Ftab}=3.54\right)$, there was a positive linear effect of the addition of CS and MF on the diameter and expansion factor of the cookies, respectively. Cookies with greater diameters and expansion factors (ratio of diameter/thickness) had higher percentages of MF and CS, and consequently, lower percentages of BF. However, the influence of MF was higher than CS in both cases, possibly because MF was used as flour and CS as seeds.

This is probably because MF presented a starch paste with lower protein and fiber contents, and lower viscosity, with greater dough spreading ability during baking. This generated a greater cookie diameter and, consequently, a greater expansion factor, since this parameter takes into account the diameter. BF, by having a higher fiber content and a more viscous paste, kept the initial diameter of the cookies after baking.

The lower influence of CS is due to the fact that this raw material has a lower amount of carbohydrates (starch), contributing less to these parameters (diameter and expansion factor of the cookies). Besides, CS was used as seeds, presenting a smaller contact surface with the other ingredients of the formulation.

Figure 1C (Thickness $(\mathrm{mm})=14-0.76 x_{1}-0.30 x_{1}^{2}-1.73 x_{2}-0.56 x_{2}^{2}-0.29 x_{1} x_{2}$; $\mathrm{R}^{2}=98.23 \% ; \mathrm{Fcal} / \mathrm{Ftab}=16.11$ ) shows that the greatest thickness values were observed for the formulations containing lower MF and CS, and higher BF levels. The MF showed higher influence (negative) on thickness of the cookies. These results are related to the constituents of the raw materials. Cookies with higher BF levels showed a smaller diameter and expansion factor and increased thickness, possibly due to a higher content of fiber and protein when compared to the formulations with higher MF levels (F4 and F8). Furthermore, the BF starch pastes were more viscous when compared to the pastes prepared with the other raw materials (Table 3), which may have contributed to the increase in vertical expansion, reducing the diameter. On the other hand, cookies formulated with higher percentages of MF presented greater spreadability due to the lower viscosity of the starch paste, with the dough flowing more easily during baking, and not maintaining the shape of the cookies.

According to Gutkoski et al. (2003), the main evaluation criteria for cookies are diameter, thickness, and surface characteristics, and a greater diameter is associated with soft wheats, low protein content, and small particle size. Our standard was the cookie prepared with $100 \%$ WF. The cookies elaborated with 
MF showed greater dough spread during baking, giving rise to a greater diameter and a lower thickness.

As reported by Moretto \& Fett (1999), in addition to the chemical composition of the raw materials, sugar and fat interfere with spread and expansion of the cookies during baking. Although these ingredients are important for the quality of the final product, no significant effect was observed in this study, since the amounts were fixed for all formulations.

With respect to texture, an increase in hardness (Figure 1D, Hardness $=51.44+11.84 x_{1}^{2}+29.88 x_{2}+38.84 x_{2}^{2} ; \mathrm{R}^{2}=89.80 \%$; Fcal/Ftab $=6.69)$ was observed in cookies with higher MF levels. Greater hardness was observed in the cookies with the increase in MF and decrease in BF levels, while CS did not have any influence on this response.

Hardness of cookies is caused by the starch-protein interactions, through hydrogen bonds, which can explain hardness of the control cookies made with WF (Hoseney, 1994). However, high hardness values were found for cookies with higher MF levels, probably due to dough spread during cooking, making cookies dry and consequently harder (Sarabhai \& Prabhasankar, 2015).

The variation range in hardness values observed for the central points in the experimental design (F9, F10 and F11) can be explained by CS addition. The seeds may have been distributed differently in the test samples used for texture evaluation (Sarabhai \& Prabhasankar, 2015).

Observing the viscoamylographic profile and composition of the raw materials (Table 3 ) together with cookie quality parameters (and taking the WF control cookie as a basis), it was found that the higher viscosity, and higher fiber and protein contents of BF led to smaller diameters, and increased thickness of the cookies (Table 4), while those cookies made with MF (which presented lower viscosity, fiber and protein contents) had an increase in the expansion factor, and hardness.

However, as the cookies contain considerable amounts of non-gelatinized starch (Duta \& Culetu, 2015), the RVA cannot fully explain the differences observed in cookie parameters. RVA analysis is carried out in excess of water, with temperatures up to $95^{\circ} \mathrm{C}$ and constant stirring, while cookie dough has less water, a considerable amount of fat and sugar, and is submitted to higher temperatures $\left(>200^{\circ} \mathrm{C}\right)$ without agitation during baking.

\subsection{Definition of the ideal cookie (optimal point) and validation of the mathematical models}

Considering the significant effects on the dependent variables or responses (diameter, expansion factor, thickness, and hardness) of the independent variables (MF, CS, and BF), and their important role for industrial production and quality of cookies, the optimum point was defined as one that presented characteristics similar to the control cookie. To obtain the predicted values of these variables (quality characteristics) similar to the control, an experimental cookie (optimum point) with $7.5 \% \mathrm{CS}\left(\mathrm{x}_{1}\right), 40 \% \mathrm{MF}\left(\mathrm{x}_{2}\right)$ (coded values for $\mathrm{x}_{1}=0.7050$ and $\mathrm{x}_{2}=-0.3525$, respectively) and $52.5 \% \mathrm{BF}\left(100-\mathrm{x}_{1}+\mathrm{x}_{2}\right)$ was produced.
Table 5. Experimental physical characteristics of the ideal cookie.

\begin{tabular}{lccc}
\hline \multicolumn{1}{c}{ Characteristics } & $\begin{array}{c}\text { Control } \\
100 \% \mathrm{WF}\end{array}$ & Real value & $\begin{array}{c}\text { Predicted } \\
\text { value }\end{array}$ \\
\hline Diameter $(\mathrm{mm})$ & $69.80 \pm 0.61$ & $65.53 \pm 0.60$ & 74.53 \\
Thickness (mm) & $15.90 \pm 0.90$ & $14.30 \pm 0.20$ & 13.79 \\
Expansion factor & 4.40 & 4.58 & 6.26 \\
Hardness $(\mathrm{N})$ & $174.38 \pm 14.21$ & $73.03 \pm 17.20$ & 51.63 \\
\hline WF = wheat flour. & & &
\end{tabular}

The results of the physical tests for the optimal point are shown in Table 5.

We can see that the results of the real (experimental) values for the ideal cookie quality parameters diameter, thickness and expansion factor are close to the values predicted by the mathematical models and close to those found for the control cookie (100\% WF).

The real value of the ideal cookie for hardness is close to the value predicted by the mathematical model, but not to that of the control cookie. It is known that instrumental texture analysis of some foods presents high variability. This may be so for cookies, especially those with inclusions such as chia seeds.

To obtain gluten-free cookies with hardness values similar to the control, higher MF levels may be necessary. However, as previously discussed, hardness of the cookies produced with MF is probably due to the greater dough spread during cooking, unlike what happens in the control cookie (produced with WF), where there is greater interaction between the components.

\subsection{SEM of control and ideal cookie}

As can be seen in Figure 2, control and ideal cookie (optimal point) micrographs with different levels of magnification (200x and 1000x) show similar structures, the small differences are due to the raw materials used in each formulation.

The control cookie presents a structure formed by the interaction between gluten-forming proteins, starch, and fat. The granules are almost entirely covered by a thin protein film and melted and re-solidified fat, as can be seen in Figures 2A and 2B. Meanwhile, the gluten-free cookie (optimum point) consists of starch granules surrounded by a non-gluten-forming protein film (probably more fragile) and melted and re-solidified fat (Figures 2C and 2D). Although the raw materials used in the gluten-free formulation presented a percentage of proteins close to $\mathrm{WF}$, the absence of gluten-forming proteins was probably responsible for the more fragile structure of the gluten-free cookies, taking into account that the rest of the formulation was the same.

The small differences between the micrographs are probably due to the different morphological properties of starches with different gelatinization stages in the cookies, conferring a gummy appearance to the control (Sarabhai \& Prabhasankar, 2015). However, the figures show that there are non-gelatinized granules, as also observed by Duta \& Culetu (2015). 

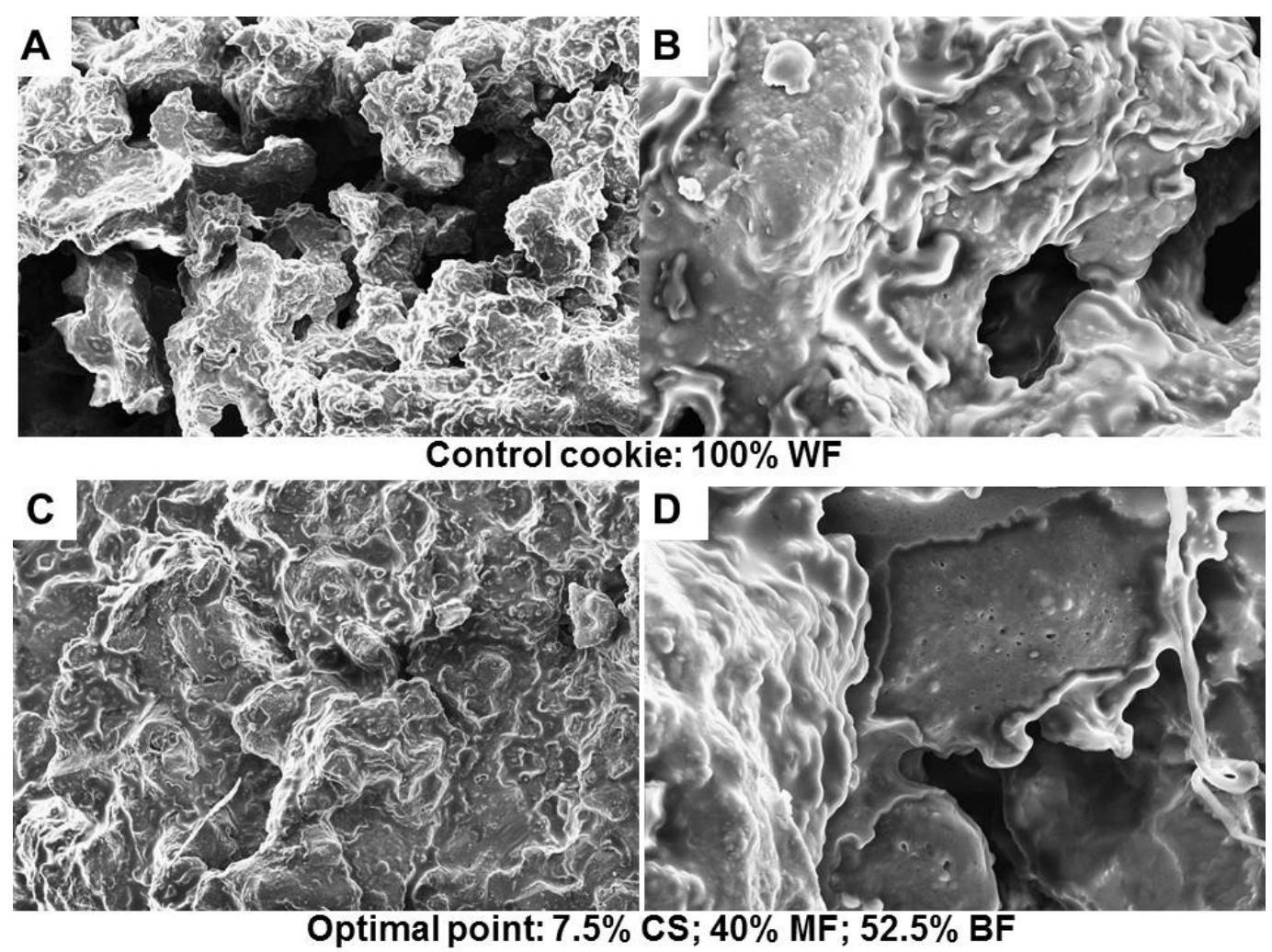

Figure 2. Micrographs of (A) control cookie at 200x magnification; (B) control cookie at 1000x magnification; (C) optimum point at 200x magnification; (D) optimum point at 1000x magnification. $\mathrm{WF}=$ wheat flour; $\mathrm{CS}=$ chia seeds; $\mathrm{MF}=$ millet flour; $\mathrm{BF}=$ buckwheat flour.

\section{Conclusions}

The results showed that cookies produced with millet flour (MF) presented greater hardness values, while buckwheat flour (BF) contributed to the increased thickness of the cookies. In contrast, chia seeds (CS) showed no influence on the responses assessed (except greater variability in the texture analysis), with possible incorporation of up to $10 \%$, which is of great importance due to its many nutritional benefits.

A greater proportion of buckwheat flour could be incorporated into the dough of gluten-free cookies to obtain diameter and thickness values similar to a cookie produced with gluten (wheat flour). However, sensory analysis should be included in future studies, since buckwheat is known for its pronounced flavor.

From the results of this study, we can conclude that the replacement of wheat flour by buckwheat flour, millet flour, and chia seeds can be a suitable alternative for the manufacture of cookies, and also for gluten-free diets.

\section{References}

Abdel-Aal, E., \& Wood, P. J. (2005). Specialty grains for food and feed. St. Paul: AACC.

Ačko, D. K. (2012). Importance and possibilities of proso millet (Panicum miliaceum L.) production for human nutrition, and animal feed in Slovenia. Journal of Food Agriculture and Environment, 10, 636-640.
American Association of Cereal Chemists - AACC. (2010). Approved methods of analysis. Method 26-50.01: brabender Quadrumat Jr. (Quadruplex) method. Method 44-15.02: moisture-air-oven methods. Method 08-01.01: ash-basic method. Method 46-13.01: crude protein. Method 30-10.01: crude fat in flour, bread and baked cereal products. Method 32-05.01: total dietary fiber. Method 66-20.01: determination of granularity of semolina and farina: sieving method. Method 26-50.01: baking quality if cookie flour (11th ed.). St. Paul: AACC.

Anderson, J. W., Baird, P., Davis, R. H. Jr., Ferreri, S., Knudtson, M., Koraym, A., Waters, V., \& Williams, C. L. (2009). Health benefits of dietary fiber. Nutrition Reviews, 67(4), 188-205. http://dx.doi. org/10.1111/j.1753-4887.2009.00189.x. PMid:19335713.

Arendt, E. K., \& Dal Bello, F. (2009). The science of gluten-free foods and beverages. St. Paul: AACC. http://dx.doi.org/10.1094/9781891127670.

Ascheri, D. P. R., Boêno, J. A., Bassinello, P. Z., \& Ascheri, J. L. R. (2012). Correlação entre as propriedades nutricionais dos grãos e viscosidade de pasta de farinhas pré-gelatinizadas de arroz vermelho. Revista Ceres, 59(1), 16-24. http://dx.doi.org/10.1590/ S0034-737X2012000100003.

Brasil, Ministério da Agricultura, Pecuária e Abastecimento. (2005, June 3). Regulamento técnico de identidade e qualidade da farinha de trigo (Instrução Normativa ${ }^{\circ} 8$, de 2 de junho de 2005). Diário Oficial [da] República Federativa do Brasil.

Capitani, M. I., Sportorno, V., Nolasco, S. M., \& Tomás, M. C. (2012). Caracterização físico química e funcional dos subprodutos de semente de chia (Salvia hispanica L.) da Argentina. Food Science and Technology, 45, 94-102. 
Chandrasekara, A., Naczk, M., \& Shahidi, F. (2012). Effect of processing on the antioxidant activity of millet grains. Food Chemistry, 133(1), 1-9. http://dx.doi.org/10.1016/j.foodchem.2011.09.043.

Charalampopoulos, D., Wang, R., Pandiella, S. S., \& Webb, C. (2002). Application of cereals and cereal components in functional foods: a review. International Journal of Food Microbiology, 79(1-2), 131-141. http://dx.doi.org/10.1016/S0168-1605(02)00187-3. PMid:12382693.

Chen, J., Deng, Z., Wu, P., Tian, J., \& Xie, Q. (2010). Effect of gluten on pasting properties of wheat starch. Agricultural Sciences in China, 9(12), 1836-1844. http://dx.doi.org/10.1016/S1671-2927(09)60283-2.

Choi, S., \& Ma, C. (2006). Extraction, purification and characterization of globulin from common buckwheat (Fagopyrum esculentum Moench) seeds. Food Research International, 39(9), 974-981. http:// dx.doi.org/10.1016/j.foodres.2006.06.004.

Coelho, M. S., \& Salas-Mellado, M. M. (2015). Effects of substituting chia (Salvia hispanica L.) flour or seeds for wheat flour on the quality of the bread. Lebensmittel-Wissenschaft + Technologie, 60(2), 729-736. http://dx.doi.org/10.1016/j.lwt.2014.10.033.

Demiate, I. M., \& Kotovicz, V. (2011). Cassava starch in the Brazilian food industry. Food Science and Technology, 31(2), 388-397. http:// dx.doi.org/10.1590/S0101-20612011000200017.

Demirbas, A. (2005). $\beta$-Glucan and mineral nutrient contents of cereals grown in Turkey. Food Chemistry, 90(4), 773-777. http:// dx.doi.org/10.1016/j.foodchem.2004.06.003.

Duta, D. E., \& Culetu, A. (2015). Evaluation of rheological, physicochemical, thermal, mechanical and sensory properties of oat-based gluten free cookies. Journal of Food Engineering, 162, 1-8. http://dx.doi.org/10.1016/j.jfoodeng.2015.04.002.

Food and Agriculture Organization of the United Nations - FAO. (2011). Food and agriculture data. Rome. Retrieved from http:// faostat.fao.org/site/291/default.aspx

Feddern, V., Durante, V. V. O., \& Miranda, M. Z. (2011). Avaliação física e sensorial de biscoitos tipo cookie adicionados de farelo de trigo e arroz. Brazilian Journal of Food Technology, 14(04), 267-274. http://dx.doi.org/10.4260/BJFT2011140400032.

Feighery, C. (1999). Fortnightly review: coeliac disease. BMJ, 319(7204), 236-239. http://dx.doi.org/10.1136/bmj.319.7204.236. PMid:10417090.

Granato, D., \& Ellendersen, L. S. N. (2009). Almond and peanut flours supplemented with iron as potential ingredients to develop gluten-free cookies. Food Science and Technology, 29(2), 395-400. http://dx.doi.org/10.1590/S0101-20612009000200026.

Gutkoski, L. C., Nodari, M. L., \& Jacobsen, N. R. No. (2003). Avaliação de farinhas de trigos cultivados no rio grande do sul na produção de cookies. Ciência e Tecnologia dos Alimentos, 23, 91-97. http:// dx.doi.org/10.1590/S0101-20612003000400017.

Hoseney, R. C. (1994). Principles of cereal science and technology (2nd ed.). St. Paul: AACC International.

Hung, P. V., Maeda, T., \& Morita, N. (2009). Buckwheat starch: structure and characteristics: a review. The European Journal of Plant Science and Biotechnology, 3, 23-28.

Ikeda, S., \& Yamashita, Y. (1994). Buckwheat as a dietary source of zinc, copper and manganese. Fagopyrum, 14, 29-34.

Inglett, G. E., Xu, J., Stevenson, D. G., \& Chen, D. (2009). Rheological and pasting properties of buckwheat (Fagopyrum esculentum Möench) flours with and without jet-cooking. Cereal Chemistry, 86(1), 1-6. http://dx.doi.org/10.1094/CCHEM-86-1-0001.

International Association for Cereal Science and Technology - ICC. (1996). Standard methods: method 162: rapid pasting method using the Newport Rapid Visco Analyser. Hamburg: ICC. Retrieved from https://www.icc.or.at/standard_methods/162

Mauro, A. K., Silva, V. L. M., \& Freitas, M. C. J. (2010). Caracterização física, química e sensorial de cookies confeccionados com farinha de talo de couve (FTC) e farinha de talo de espinafre (FTE) ricas em fibra alimentar. Food Science and Technology, 30(3), 719-728. http://dx.doi.org/10.1590/S0101-20612010000300024.

Moretto, E., \& Fett, R. (1999). Processamento e análise de biscoitos. São Paulo: Varela.

Moroni, A. V., Bello, F. D., Zannini, E., \& Arendt, E. K. (2011). Impact of sourdough on buckwheat flour, batter and bread: biochemical, rheological and textural insights. Journal of Cereal Science, 54(2), 195-202. http://dx.doi.org/10.1016/j.jcs.2011.04.008.

Muñoz, L. A., Cobos, A., Diaz, O., \& Aguilera, J. M. (2012). Chia seeds: microstructure, mucilage extraction and hydration. Journal of Food Engineering, 108(1), 216-224. http://dx.doi.org/10.1016/j. jfoodeng.2011.06.037.

Murray, J. A. (1999). The widening spectrum of celiac disease. The American Journal of Clinical Nutrition, 69(3), 354-365. PMid:10075317.

Nuwamanya, E., Baguma, Y., Emmambux, N., Taylor, J., \& Patrick, R. (2010). Physicochemical and functional characteristics of cassava starch in Ugandan varieties and their progenies. Journal of Plant Breeding and Crop Science, 2, 1-11.

Pomeranz, Y. (1988). Wheat: chemistry and technology (3rd ed., Vol. 2). St. Paul: AACC.

Ragaee, S., \& Abdel-Aal, E. M. (2006). Pasting properties of starch and protein in selected cereals and quality of their food products. Food Chemistry, 95(1), 9-18. http://dx.doi.org/10.1016/j. foodchem.2004.12.012.

Reyes-Caudillo, E., Tecante, A., \& Valdivia-López, M. A. (2008). Dietary fibre content and antioxidant activity of phenolic compounds present in Mexican chia (Salvia hispanica L.) seeds. Food Chemistry, 107(2), 656-663. http://dx.doi.org/10.1016/j.foodchem.2007.08.062.

Rostom, A., Dubé, C., Cranney, A., Saloojee, N., Sy, R., Garritty, C., Sampson, M., Zhang, L., Yazdi, F., Mamaladze, V., Pan, I., Macneil, J., Mack, D., Patel, D., \& Moher, D. (2005). The diagnostic accuracy of serologic tests for celiac disease: a systematic review. Gastroenterology, 128(4, Suppl 1), S38-S46. http://dx.doi.org/10.1053/j. gastro.2005.02.028. PMid:15825125.

Sarabhai, S., \& Prabhasankar, P. (2015). Influence of whey protein concentrate and potato starch on rheological properties and baking performance of Indian water chestnut flour based gluten free cookie dough. Lebensmittel-Wissenschaft + Technologie, 63(2), 1301-1308. http://dx.doi.org/10.1016/j.lwt.2015.03.111.

Schirmer, M., Höchstötter, A., Jekle, M., Arendt, E., \& Becker, T. (2013). Physicochemical and morphological characterization of different starches with variable amylose/amylopectin ratio. Food Hydrocolloids, 32(1), 52-63. http://dx.doi.org/10.1016/j. foodhyd.2012.11.032.

Silva, M. R., Silva, M. A. A. P., \& Chang, Y. K. (1999). Uso de farinha de jatobá (Hymenaea sp.) em biscoitos tipo "cookie". Alimentos e Nutrição, 10, 7-22.

Silva, R. F., Ascheri, J. L. R., Pereira, R. G. F. A., \& Modesta, R. C. D. (2009). Aceitabilidade de biscoitos e bolos à base de arroz com café extrusados. Ciência e Tecnololia de Alimentos, 29(4), 815-819. http://dx.doi.org/10.1590/S0101-20612009000400018.

Singh, S., Singh, N., \& MacRitchie, F. (2011). Relationship of polymeric proteins with pasting, gel dynamic- and dough empirical-rheology in different Indian wheat varieties. Food Hydrocolloids, 25(1), 1924. http://dx.doi.org/10.1016/j.foodhyd.2010.05.001. 
StatSoft. (2004). Statistica for Windows, release 7.0. Tulsa.

Torbica, A., Hadnađev, M., \& Hadnađev, T. D. (2012). Rice and buckwheat flour characterisation and its relation to cookie quality. Food Research International, 48(1), 277-283. http://dx.doi. org/10.1016/j.foodres.2012.05.001.

Yamamoto, H., Worthigton, S. T., Hou, G., \& Ng, P. K. W. (1996). Rheological properties and baking qualities of selected soft wheats grown in the United States. Cereal Chemistry, 73(2), 215-221.
Zhang, Y., Nagamine, T., He, Z. H., Ge, X. X., Yoshida, H., \& Peña, R. J. (2005). Variation in quality traits in common wheat as related to Chinese fresh white noodle quality. Euphytica, 141(1-2), 113-120. http://dx.doi.org/10.1007/s10681-005-6335-0.

Zheng, G. H., Sosulski, F. W., \& Tyler, R. T. (1998). Wet-milling, composition and functional properties of starch and protein isolated from buckwheat groats. Food Research International, 30(7), 493-502. http://dx.doi.org/10.1016/S0963-9969(98)00021-0. 